DOI: 10.17707/AgricultForest.65.4.21

\begin{abstract}
Mykola KHARYTONOV*, Nadiia MARTYNOVA, Mykhaylo BABENKO, Iryna RULA, Mykhaylo GUMENTYK, Maria BAGORKA, Valentina PASHOVA ${ }^{1}$
\end{abstract}

\title{
THE PRODUCTION OF BIOFUEL FEEDSTOCK ON RECLAIMED LAND BASED ON SWEET SORGHUM BIOMASS
}

\begin{abstract}
SUMMARY
Almost all of the studied sorghum hybrids showed a good growth both on the black soil mass and on loess-like loam. The yield of fresh biomass was reached at the level of 50-100 $\mathrm{t} \mathrm{ha}^{-1}$. The juice amount in the stems of Ukrainian hybrids was more than in American ones by 5-10\%. At the same time, the concentration of sugar in it was less, $16-19 \%$ as against $18-21 \%$. The theoretical ethanol yield for highly productive hybrids (Zubr, Medove, Mohawk, SS506) was 2500-3600 L ha-1, and for low-output hybrids (Sioux and Silosne-42) 705$1600 \mathrm{~L} \mathrm{ha}^{-1}$. Hybrids Zubr, Medove, Mohawk, SS506 and G1990 were selected as the most promising for cultivation on reclaimed lands. Addition of the plant biomass to sludge activates the thermal behavior of the composite mix. As a result, the combustion level rises to $41.4 \%$.
\end{abstract}

Keywords: sweet sorghum, reclaimed lands, biomass productivity, theoretical ethanol yield, thermal effects.

\section{INTRODUCTION}

Sweet sorghum is a promising, drought-resistant plant which has a number of useful features and a great potential for use in various areas of the national economy of Ukraine (Mostenska et al., 2013; Rakhmetov et al., 2018 The juice extracted from the fresh stem can be used to produce sugar, syrup and first generation bioethanol (Sipos et al., 2009; Kim and Day, 2011). Bagasse can be used as fodder, fertiliser, second generation bioethanol or as a raw material for the paper industry (Betancur and Pereira, 2010). Sorghum stems contain readily available soluble carbohydrates, so enzymatic conversion of starch into sugar is not necessary. This gives sorghum an economic advantage over other starchbased crops. High sugar content and ease of extractability make sweet sorghum one of the leading feedstock crops for biofuels (Taylor et al., 2006, Mathur et al., 2017). Agronomic traits like short life cycle of about 4 months, C4 photosynthesis which contributes to higher water and nutrient use efficiency,

\footnotetext{
${ }^{1}$ Mykola.Kharytonov (corresponding author: kharytonov.m.m@dsau.dp.ua), Mykhailo Babenko, Iryna Rula, Maria Bagorka, Valentina Pashova, Dnipro State Agrarian and Economic University, Dnipro, UKRAINE, Nadiia Martynova, Oles Honchar Dnipro National University, Dnipro, UKRAINE, Mykhaylo Gumentyk, Institute of energy crops and sugar beet NAASU, Kyiv, UKRAINE

Notes: The authors declare that they have no conflicts of interest. Authorship Form signed online.
} 
unpretentiousness and low cost of cultivation are especially helpful for its adoption as a raw material (Reddy et al., 2005; Shoemaker et al., 2010; Rutto et al., 2013; Regassa and Wortmann, 2014). The unpretentiousness of sorghum to environmental conditions determines the prospect of growing this plant on unproductive and reclaimed lands, thus avoiding a conflict between food production and biofuels (Ameen et al., 2017; Mehmood et al., 2017). There are some data of sorghum cultivation in marginal lands. For example, in Northern and Eastern China, the biomass yield, nutrient (N, P, and $\mathrm{K}$ ) accumulation and energy productivity of sorghum on marginal lands conditions under arid and semi arid conditions were studied (Ren et al., 2012; Fu at al., 2016). In USA, Holou and Stevens (2012) investigated the optimum nitrogen fertilizer rate for producing sweet sorghum juice, sugar, and bagasse on silt loam, sandy loam, and clay soils. Asif Ameen and colleagues studied the potential energy sorghum biomass production and uptake of nitrogen $(\mathrm{N})$, phosphorus $(\mathrm{P})$, and potassium (K) on a sandy loam marginal land (Ameen et al., 2017). Given the specifics of reclaimed land, the selection of energy sorghum genotypes in such conditions should be based on the following criteria: fast and homogeneous germination; the ability to produce a stably high biomass yield; high sugar content in stem juice; disease resistance (Adeyanju et al., 2015). Nevertheless, the matter of selection of the most productive hybrids and the technologies of sorghum cultivation under unproductive lands conditions have not been sufficiently studied, so the need for research in this direction is urgent.

The utilization of different kinds of biomass residues become an important part of future bio-energy concept (Curovic et al., 2016; Steite et al., 2011). Last years the sewage sludge as residual waste of sewage plants is applied to mix with different kinds of crop residues for pelletization (Li et al., 2015).

The main objective was to give the bio-energetic assessment of the production of bio-fuel feedstock on reclaimed land based on sweet sorghum biomass.

\section{MATERIAL AND METHODS}

This research was carried out under Ukraine steppe zone conditions at Pokrov land reclamation station of Dnipro State Agrarian and Economic University in 2017 and 2018. Four sweet sorghum hybrids of Ukrainian selection (Medove, Zubr, Pokrovske, Silosne-42) and four American hybrids (SS506, Sioux, Mohawk, G1990) were investigated in the field. Experience was carried out in two versions. In the first case the plants were grown on long-term plant meliorated loess-like loam (LLL), in the second on the black soil (BS) mass taken in stockpiling. The humus content in the loess-like loam is about $1.1 \%$, in the black soil is 3.3. The ratio of humic and fulvic acids is 0.65 (LLL) and 1.36 (BS). Sorghum seeds were sown in early May. Biometric indices, productivity, conservative sugar yield, and theoretical ethanol yield were researched. The plant height was measured using a measuring line. To determine the yield of aboveground biomass, each cultivar was harvested after the grain reached hard dough 
stage by cutting at the height of $10 \mathrm{~cm}$ from the ground level and weighed. After that, the biomass was dried to constant weight, and then weighed again. The sugar concentration in sweet sorghum stalks is measured in Brix units, which represents the percent soluble sugars. One degree Brix is equal to $1 \mathrm{~g}$ of sugar per $100 \mathrm{~g}$ of juice. Brix was determined using a hand-held refractometer "RHBO50ATC”. Conservative sugar yield $\left(\mathrm{t} \mathrm{ha}^{-1}\right)$ was calculated based on an approach assuming that the sugar concentration is $75 \%$ of Brix expressed in $\mathrm{g} \mathrm{kg}^{-1}$ sugar juice (Wortmann et al., 2010; Ekefre et al., 2017). It was used the equation: CSY $=($ FSY-DSY $) *$ Brix*0.75. Where, CSY is conservative sugar yield $\left(\mathrm{t} \mathrm{ha}^{-1}\right)$, FSY is fresh stem yield $\left(\mathrm{t} \mathrm{ha}^{-1}\right)$, DSY is dry stem yield $\left(\mathrm{tha}^{-1}\right)$. Theoretical ethanol yield was calculated as sugar yield multiplied by a conversion factor $(0.58 \mathrm{~L}$ ethanol per kg of sugar): TEY=CSY*0.58 (Rutto et al., 2013; Ekefre et al., 2017). Where, TEY is theoretical ethanol yield ( $\left.\mathrm{L} \mathrm{ha}^{-1}\right)$, CSY is conservative sugar yield $\left(\mathrm{kg} \mathrm{ha}^{-1}\right)$.

The sorghum biomass and dewatered sewage sludge were taken as raw material. The sludge was obtained from an urban sewage station in Kiev city (Ukraine). Sludge and sorghum biomass sample were mixed manually with ratio of $50 \mathrm{wt} . \%$. The thermal analysis of plant biomass was carried out using the derivatograph Q-1500D of the "F. Paulik-J. Paulik-L. Erdey" system. Differential mass loss and heating effects were recorded. The results of the measurements were processed with the software package supplied with the device. Samples of biomass were analyzed dynamically at a heating rate of $10^{\circ} \mathrm{C} / \mathrm{min}$ in an air atmosphere. The mass of samples was $100 \mathrm{mg}$.

\section{RESULTS AND DISCUSSION}

The cultivation of sweet sorghum on different mining substrates detected some variations in growth indicators. Cultivars Zubr and Medove showed the best growth characteristics on loess-like loam whereas Pokrovske, Silosne-42 and all American hybrids grew better on black soil (Figure 1).

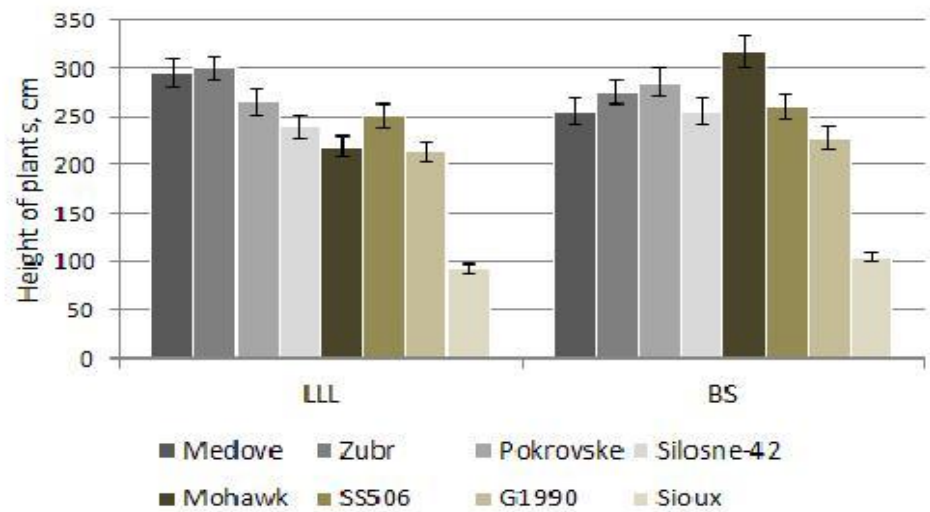

Figure 1. Height of sweet sorghum hybrids grown on reclaimed lands.

Mainly, the height of the studied cultivars was lower than the potentially average, by $9-25 \%$ on black soil, and by $22-37 \%$ on loess-like loam. The 
smallest height was noted for Sioux on both substrates. It was not more than 95$105 \mathrm{~cm}$ with a potential height of 200-250 cm. By different assessments (Almorades and Hadi, 2009; Erickson et al., 2011; Regassa and Wortmann, 2014; Cavalaris et al., 2017), depending upon the cultivar, climate and soil conditions, and the planting date etc., productivity of sorghum fresh biomass can vary within a wide ranges, from 35 to $145 \mathrm{t} \mathrm{ha}^{-1}$. In our experiment, as shown in the Figure 2, fresh biomass yield was recorded on loess-like loam from $18.9 \mathrm{t} \mathrm{ha}^{-1}$ (Sioux) to $101.0 \mathrm{t} \mathrm{ha}^{-1}$ (Zubr), and on black soil from $37.5 \mathrm{t} \mathrm{ha}^{-1}$ (Sioux) to $80.7 \mathrm{t} \mathrm{ha}^{-1}$ (SS506).

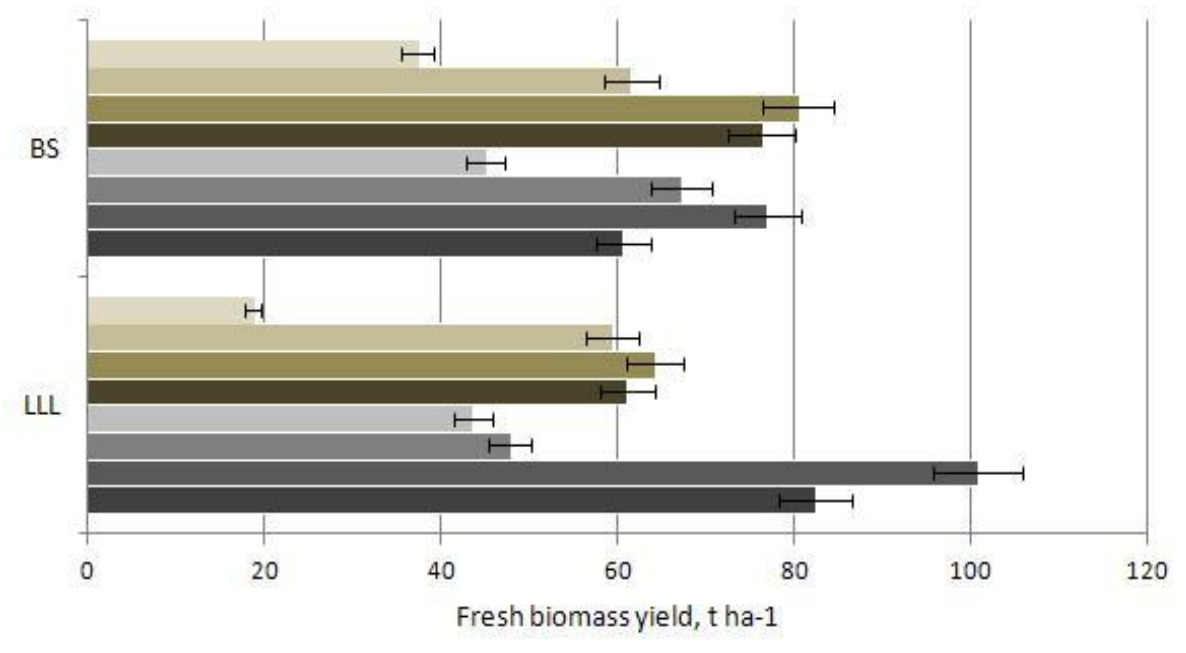

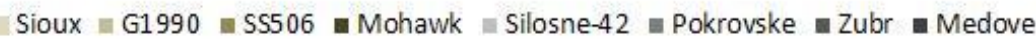

Figure 2. Fresh biomass yield of sweet sorghum hybrids grown on reclaimed lands.

During the experiment, it was defined that juice amount in the stems of Ukrainian hybrids was more than in American ones by 5-10\%. At the same time, the concentration of sugar in it was less, $16-19 \%$ as against $18-21 \%$. The plants grown on the black soil mass had Brix values slightly higher than on loess-like loam. As a result, on loess-like loam conservative sugar yield varied from 1.2 to $6.2 \mathrm{tha}^{-1}$, and on black soil from 2.2 to $4.9 \mathrm{tha}^{-1}$. The highest yield was noted for Zubr, and lowest for Sioux. The theoretical ethanol yield for highly productive hybrids (Zubr, Medove, Mohawk, SS506) was 2500-3600 L ha ${ }^{-1}$, and for lowoutput hybrids (Sioux and Silosne-42) 705-1600 L ha-1 (Figure 3). Medove and Zubr were more productivity on the loess-like loam, and other hybrids on the black soil.

Thermal analysis of sorghum biomass, sludge, and composite mix of sludge and biomass showed the almost complete absence of sludge thermal degradation. The process occurs in the temperature range from $60^{\circ} \mathrm{C}$ to $550^{\circ} \mathrm{C}$, and the level of decomposition is only $15.5 \%$ (Figure 4 ). 


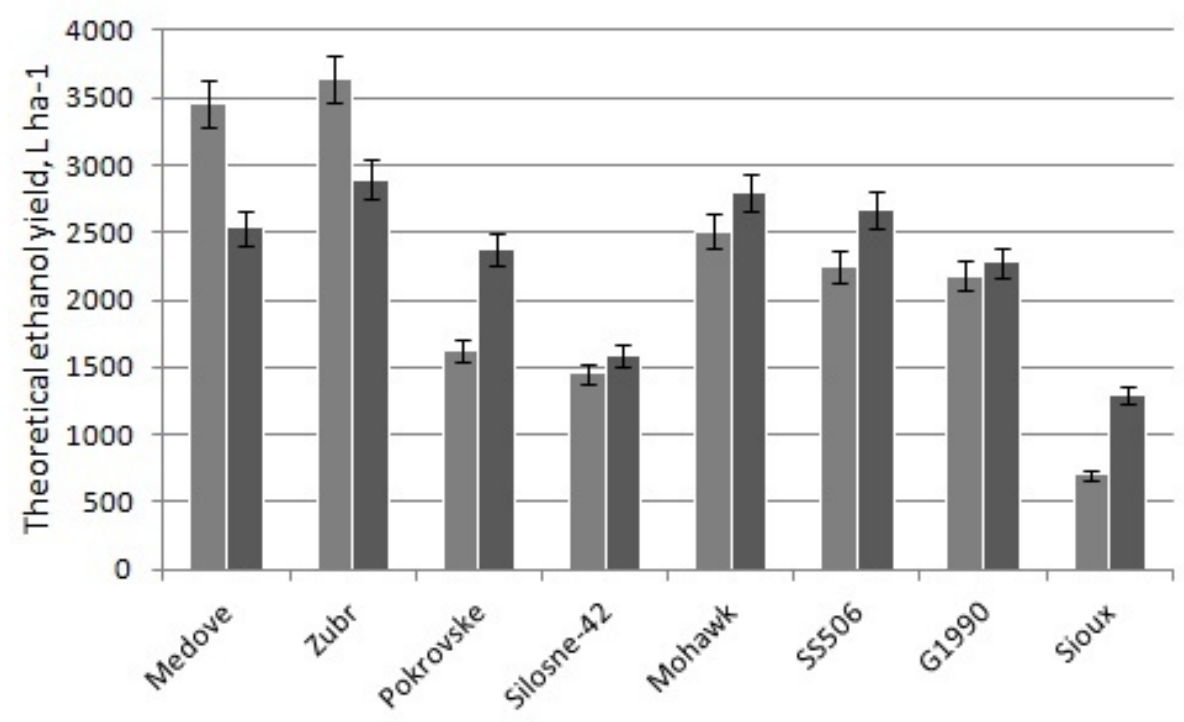

$\square$ LLL $\square$ BS

Figure 3. Potential ethanol yield per area in sweet sorghum hybrids grown on reclaimed lands.

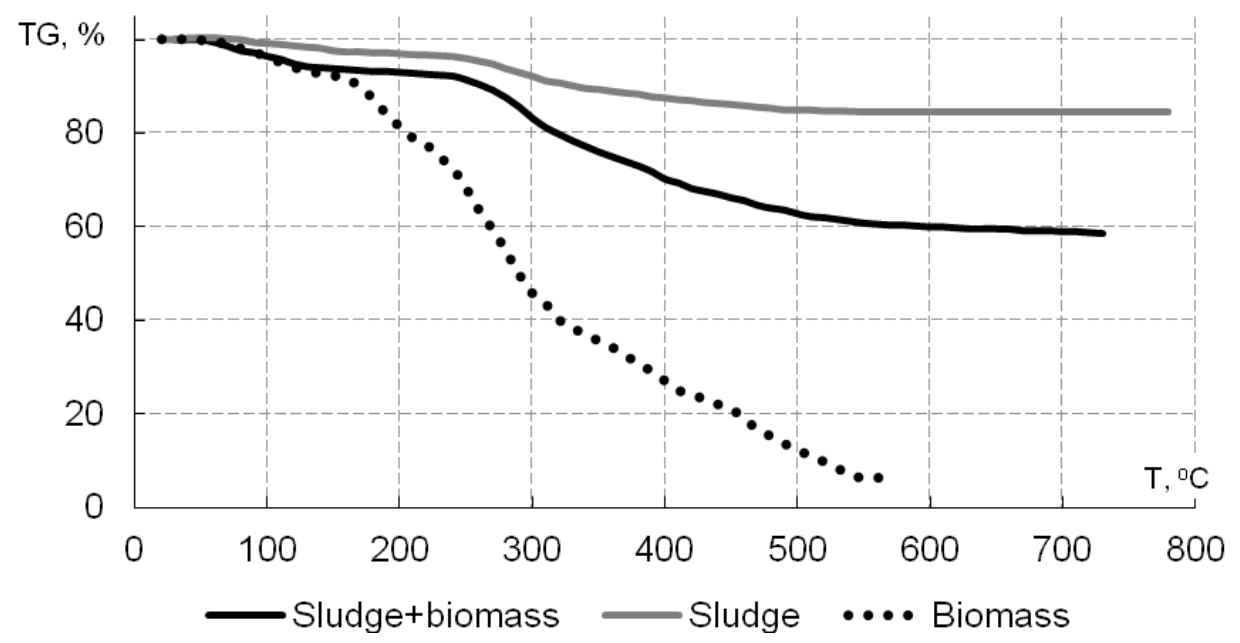

Figure 4. TG curves of biomass, sludge, and mix of sludge and biomass thermal destruction

Addition of the plant biomass to sludge activates the thermal behavior of the composite mix, as a result, the combustion level rises to $41.4 \%$. The process takes place in the range of $40-730{ }^{\circ} \mathrm{C}$ and includes three stages with characteristic peaks of decomposition rate at temperatures of $90{ }^{\circ} \mathrm{C}, 290{ }^{\circ} \mathrm{C}$ and $370{ }^{\circ} \mathrm{C}$. Pure biomass is consumed to 
93.6\% in the temperature range from $30{ }^{\circ} \mathrm{C}$ to $560{ }^{\circ} \mathrm{C}$ and embraced four stages. In all three samples, the first stage of the removal of volatile components is accompanied by the presence of endothermic reactions (Figure 5).

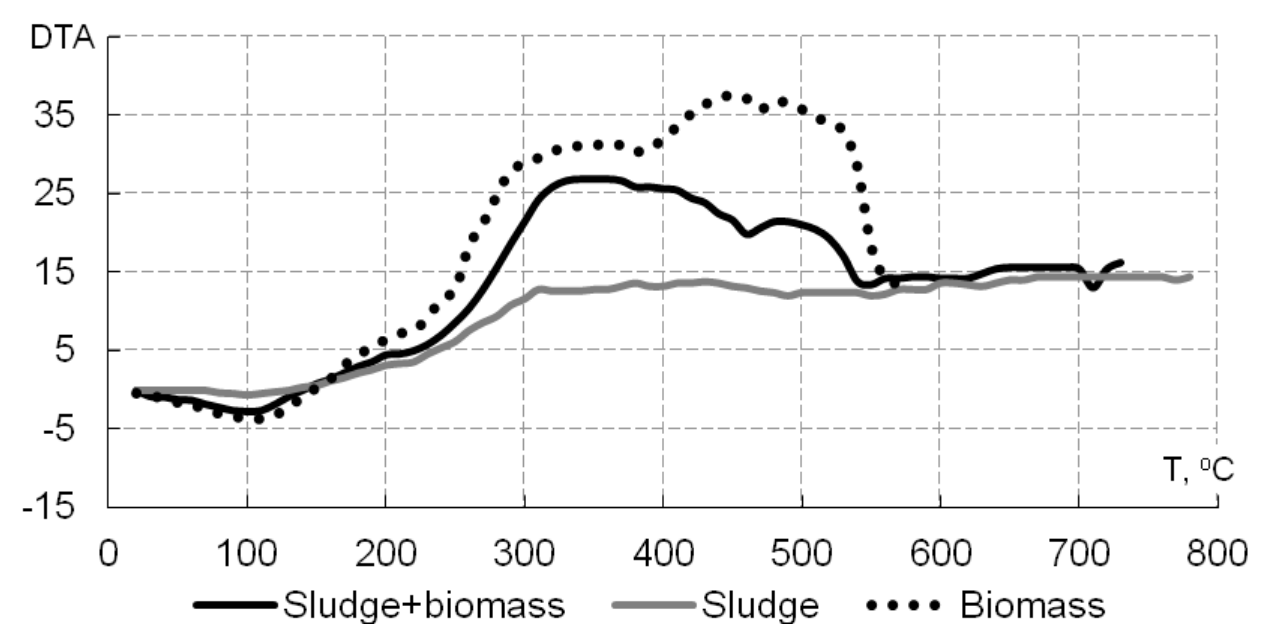

Figure 5. DTA curves of biomass, sludge, and mix of sludge and biomass thermal destruction

The starting of exothermic reactions is observed at a temperature of $140-160{ }^{\circ} \mathrm{C}$. The greatest exothermic effect was noted in the sorghum biomass sample in the temperature ranges $350-370{ }^{\circ} \mathrm{C}$ and $440-460{ }^{\circ} \mathrm{C}$. Exothermic effects in the sludge sample were very weak.

\section{CONCLUSIONS}

Almost all studied sorghum hybrids showed a good growth both on the black soil mass and on loess-like loam. Although these indicators were lower than potentially average ones by $9-37 \%$, the yield of fresh biomass was reached at the level of 50-100 $\mathrm{t} \mathrm{ha}^{-1}$. All American hybrids and Ukrainian variety Pokrovske were more productive on the black soil. The other Ukrainian cultivars were high-yielding on the loess-like loam. The juice amount in the stems of Ukrainian hybrids was more than in American ones by 5-10\%. At the same time, the concentration of sugar in it was less, $16-19 \%$ as against $18-21 \%$. The plants grown on the black soil mass had Brix values slightly higher than on loess-like loam. Thus, the theoretical ethanol yield for highly productive hybrids (Zubr, Medove, Mohawk, SS506) was 2500-3600 L ha' ${ }^{-1}$, and for low-output hybrids (Sioux and Silosne-42) 705-1600 $\mathrm{L} \mathrm{ha}^{-1}$.

Addition of the plant biomass to sludge activates the thermal behavior of the composite mix. As a result, the combustion level rises to $41.4 \%$. 


\section{REFERENCES}

Adeyanju A, Little C, Yu J, Tesso T. 2015. Genome-wide association study on resistance to stalk rot diseases in grain sorghum. G3 (Bethesda). 5(6):1165-75.

Almorades A., Hadi M.R. 2009. Production of bioethanol from sweet sorghum: A review. African Journal of Agricultural Research, vol.4(9), pp.772-780. http://www.academicjournals.org/journal/AJAR/article-full-textpdf/6DDEDD738826

Ameen A., Yang X., Chen F., Tang C., Du F., Fahad S., Xie G.H. 2017. Biomass Yield and Nutrient Uptake of Energy Sorghum in Response to Nitrogen Fertilizer Rate on Marginal Land in a Semi-Arid Region. BioEnergy Research.Volume 10, Issue 2, pp 363-37. https://doi.org/10.1007/s12155-016-9804-5

Betancur G..J.V., Pereira N.Jr. 2010. Sugar cane bagasse as feedstock for second generation ethanol production. Part I: Diluted acid pretreatment optimization. Electronic Journal of Biotechnology ISSN: 0717-3458 DOI: 10.2225/vol13issue3-fulltext-3

Cavalaris C., Merkouris O., Karamoutis C., Akademir S., Mamma D., Kekos D., Gemtos T. 2017. Effects of Row Spacing on Growth, Yield and Quality Parameters of Sweet Sorghum. Journal of Agricultural Faculty of Gaziosmanpasa University, vol.34(1), pp.229-237. doi:10.13002/ jafag4215

Curovic, M., Pavicevic, K., Djokic, M., Drobnjak, D. 2016. Analysis of the energy potential of agricultural biomass residues in Montenegro. Agriculture and Forestry, 62 (3): 277-284. DOI:10.17707/AgricultForest.62.3.22

Ekefre D.E., Mahapatra A.K., LatimoreJr.M., Bellmer D.D., Jena U., Whitehead G.J., Williams A.L. 2017. Evaluation of three cultivars of sweet sorghum as feedstocks for ethanol production in the Southeast United States. Heliyon, vol. 3. e00490, pp. 1-18. doi:10.1016/j.heliyon.2017. e00490

Erickson J.E., Helsel Z.R., Woodard K.R., Vendramini J.M.B., Wang Y., Sollenberger L.E., Gilbert R.A. 2011. Planting Date Affects Biomass and Brix of Sweet Sorghum Grown for Biofuel across Florida. Agronomy Journal, vol.103(6), pp.1827-1833. doi:10.2134/agronj2011.0176

Fu, H.M., Meng, F.Y., Molatudi, R.L. Zhang B.G. 2016. Sorghum and Switchgrass as Biofuel Feedstocks on Marginal Lands in Northern China Bioenerg. Res. Volume 9, Issue 2, pp 633-642. https://doi.org/10.1007/s12155-015-9704-0

Holou R.A., G. Stevens G. 2012). Juice, sugar, and bagasse response of sweet sorghum (Sorghum bicolor (L.) Moench cv. M81E) to N fertilization and soil type. GCB Bioenergy, 4. pp. 302-310 doi: 10.1111/j.1757-1707.2011.01126.x

Kim M., Day D.F. 2011. Composition of sugar cane, energy cane, and sweet sorghum suitable for ethanol production at Louisiana sugar mills. Journal of Industrial

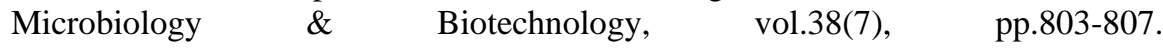
https://doi.org/10.1007/s10295-010-0812-8

Li H.,Jiang I.B.,li C.-Z.,Liang J., Yuan X.Z., Xiao Z.-H.,Wang H. 2015. Co-pelletization of sewage sludge and biomass : The energy input and propertiesof pellets. Fuel Processing Technology 132:55-61. https://dx.doi.org/10.1016/j.tuproc2014.12.20

Mathur S., Umakanth A.V., Tonapi V.A., Sharma R., Sharma M.K. 2017. Sweet sorghum as biofuel feedstock: recent advances and available resources. Biotechnol Biofuels, 10:146. https://doi.org/10.1186/s13068-017-0834-9

Mehmood M.F., M. Ibrahim, Rashid U., Nawaz M., Ali S., Hussain A., Gull G. 2017. Biomass production for bioenergy using marginal lands. Sustainable Production and Consumption. Vol.9. P.3-21. https://doi.org/10.1016/j.spc.2016.08.003 
Mostenska T., Kowalski A., Fedulova I., Wigier M., Szczepaniak I., Bilan Y. 2013. Growth and competitiveness factors of the agri-food sector in Poland and Ukraine against the background of global trends. Kyiv-Warsaw:NUFT, NRI-IAFE, CSR, $394 \mathrm{p}$.

Reddy B. V. S., Ramesh S., Reddy P. S., Ramaiah B., Salimath P. M., Rajashekar K. 2005. Sweet Sorghum -A Potential Alternate Raw Material for Bio-Ethanol and Bioenergy. International Sorghum and Millets Newsletter, Vol. 46, pp. 79-86.

URL:00b4952bd0439abc7e000000.pdf

Rakhmetov D.B., Vergun O., Blum Ya.B., Rakhmetova S.O., Fishchenko V.V. 2018. Biochemical composition of plant raw material of sweet sorghum (Sorghum saccharatum (L.) Moench) genotype. Introduction of plants journal, №3, pp..8390. DOI: $10.5281 /$ zenodo.2278755

Regassa TH, Wortmann CS. Sweet sorghum as a bioenergy crop: literature review. Biomass Bioenergy. 2014. Vol.64. P.348-355. https://doi.org/ 10.1016/j.biombioe.2014.03.052

Ren L.T., Liu Z.X., Wei T.Y., Xie G.H. 2012. Evaluation of energy input and output of sweet sorghum grown as a bioenergy crop on coastal saline-alkali land. Energy, 47,166-173. https://doi.org/10.1016/j.energy.2012.09.024

Rutto L.K, Xu Y., Brandt M., Ren Sh., Kering M.K. 2013. Juice, Ethanol, and Grain Yield Potential of Five Sweet Sorghum (Sorghum bicolor (L.) Moench) Cultivars. Journal of Sustainable Bioenergy Systems, vol. 3, pp. 113-118. http://dx.doi.org/10.4236/jsbs.2013.32016

Rutto L.K, Xu Y., Brandt M., Ren Sh., Kering M.K. 2013. Juice, Ethanol, and Grain Yield Potential of Five Sweet Sorghum (Sorghum bicolor (L.) Moench) Cultivars. Journal of Sustainable Bioenergy Systems, vol.3, pp. 113-118. http://dx.doi.org/10.4236/jsbs.2013.32016

Shoemaker C., Bransby D.I. 2010. The role of sorghum as a bioenergy feedstock.In Sustainable alternative fuel feedstock opportunities, challenges androadmaps for six US regions. Ankeny, IA: Soil and Water ConservationSociety. pp.149-159.

Sipos B., Reczey J., Somorai Z., Kadar Z., Dienes D., Reczey K. 2009. Sweet Sorghum as Feedstock for Ethanol Production: Enzymatic Hydrolysis of Steam-Pretreated Bagasse. Applied Biochemistry and Biotechnology, vol.153(1-3), pp.151-162. doi:10.1007/s12010-008-8423-9

Steite W.,Clemans C., Holm J.K.,Sanadi A.R., Abrenfeldt S., Shang I., Henriksen U.B..2011. Pelletizing properties of torrefied spruce. Biomass \& Bioenergy 35: 4690-4698. http:dx.doi.org/10.1016/j.fuproc2014.12.020

Taylor J.R.N., Schober T.J., Bean S.R. 2006. Novel food and non-food uses for sorghum and millets. Review. Journal of Cereal Science, 44(3):252-271. https://doi.org/10.1016/j.jcs.2006.06.009

Wortmann C.S., Liska A. J., Ferguson R. B., Lyon D. J., Klein R. N., Dweikat I. 2010. Dryland Performance of Sweet Sorghum and Grain Crops for Biofuel in Nebraska. Agronomy Journal, vol.102(1), pp. 319-326. doi:10.2134/agronj2009.0271 